Jurnal Teknologi, 46(E) Jun 2007: 45-60

(C) Universiti Teknologi Malaysia

\title{
TAHAP KESEDIAAN GURU SAINS DALAM PENGGUNAAN TEKNOLOGI MAKLUMAT BERASASKAN KOMPUTER DALAM PROSES PENGAJARAN DAN PEMBELAJARAN
}

\author{
MOHD. IZHAM MOHD. HAMZAH ${ }^{1^{*}} \&$ NORAINI ATTAN ${ }^{2}$
}

\begin{abstract}
Abstrak. Kajian ini bertujuan untuk meninjau tahap kesediaan guru dari aspek pengetahuan dan sikap terhadap penggunaan teknologi maklumat berasaskan komputer bagi pengajaran dan pembelajaran sains di dalam bilik darjah. Satu set soal selidik yang terdiri daripada tiga bahagian digunakan sebagai instrumen kajian. Sampel kajian terdiri daripada 223 orang guru yang mengajar sains di 22 buah Sekolah Menengah Kebangsaan yang terdapat di Daerah Hulu Langat,Selangor. Data yang diperolehi telah dijalankan penganalisisan dengan bantuan perisian komputer melalui program SPSS Version 7.5. Statistik yang digunakan ialah statistik deskriptif yang melibatkan frekuensi, skor min dan peratusan, manakala statistik inferensi melibatkan ujian- $t$ pada tahap kesignifikanan $p<0.05$. Hasil kajian menunjukkan bahawa faktor jantina tidak mempengaruhi tahap kesediaan guru dari semua aspek yang dikaji. Secara keseluruhannya tahap kesediaan penggunaan teknologi maklumat berasaskan komputer bagi guru-guru sains ini adalah sederhana. Tahap kesediaan dari aspek pengetahuan dan sikap pula, didapati tiada perbezaan yang signifikan di antara guru dari kumpulan perkhidmatan siswazah dan bukan siswazah.
\end{abstract}

Kata kunci: Tahap kesediaan guru, teknologi maklumat, proses pengajaran dan pembelajaran, sains, pengetahuan dan minat guru

\begin{abstract}
The main purpose of this study is to investigate the level of teachers' preparedness on the use of computer based information technology in the teaching and learning of science in the classroom with regards to knowledge and attitude. A set of questionnaires which contains three major parts, was used as the research instrument. A sample of 223 science teachers from 22 national secondary schools in the district of Hulu Langat, Selangor were the respondents. Data obtained was analysed using SPSS 7.5. The statistics used in this study were descriptive statistics that is frequency,mean score and percentage whereas for the inferential statistic, a $t$-test with the significance of $p<0.05$ were used. The analysis showed that the science teachers' preparedness from the aspect of knowledge and attitude is average. The findings also indicated that gender does not play a role in influencing teachers' preparedness from all the aspects mentioned above. Results from this study show that teachers' qualification do not influence science teachers' preparedness level in the aspect of knowledge and attitude.
\end{abstract}

Keywords: Teacher preparedness, information technology, teaching and learning process, science, teachers knowledge and attitude

\footnotetext{
1\&2Jabatan Asas Pendidikan, Fakulti Pendidikan, Universiti Kebangsaan Malaysia, 43600 UKM Bangi, Selangor Darul Ehsan

* Penulis utama: Tel: 03-89216263/012-7314529, E-mel: izham@pkrisc.cc.ukm.my
} 


\subsection{PENDAHULUAN}

Perkembangan terkini teknologi maklumat menjadi topik utama dalam perbincangan semasa terutamanya dalam menuju era globalisasi. Malaysia seperti negara-negara lain tidak terlepas daripada turut bersaing demi untuk meningkatkan taraf hidup masyarakat dan negara. Peranan teknologi maklumat menjadi begitu penting terutamanya dalam bidang pendidikan sebagai asas penyaluran ilmu. Penyaluran ilmu ini pula dapat disampaikan dengan berkesan melalui proses pengajaran dan pembelajaran antara guru dengan pelajar. Bermula dari kaedah pengajaran dan pembelajaran menggunakan papan dan kapur; bertukar kepada penggunaan komputer, bahan elektronik, Liquid Crystal Display (LCD), kamera video dan teknologi lain yang terdapat di dalam bilik darjah. Dari semasa ke semasa, pendidikan melalui perubahan selaras dengan kemajuan fikiran, kehendak dan teknologi pengajaran.

Teknologi maklumat berasaskan komputer bukan sahaja merupakan bahan perantara yang berpotensi dalam memudahkan kerja-kerja seharian malah ia juga dapat menjadi bahan untuk menjayakan lagi persekitaran pengajaran dan pembelajaran (Nor Hashim, Maznah \& Azlinda, 1996). Teknologi maklumat ini juga dapat menentukan bahawa sumber-sumber maklumat dapat diperolehi oleh semua dengan mudah iaitu dalam keadaan tersedia dan tanpa mengira tempat dan masanya (Chan, 1999). Teknologi maklumat ini juga dapat memberikan peluang kepada guru dan pelajar untuk meneroka ilmu mengikut kehendak dan tahap pencapaian masingmasing (Jamaluddin, Muhammad \& Abd. Rasid, 2000). Menurut Kulik dan Kulik (1991), kebanyakan pelajar mendapati berlakunya peningkatan dari segi pencapaian dalam markah-markah peperiksaan dengan menggunakan pakej bantuan komputer. Dalam ertikata lain,pengintergrasian teknologi maklumat ini tidak boleh dipisahkan dengan pengajaran dan pembelajaran di dalam kelas. Namun begitu. Menurut Honey, McMillan dan Craig (1999), guru tidak diberi penekanan tentang penggunaan bahan teknologi ini kepada pengajaran dan pembelajaran di dalam bilik darjah. Persoalannya di sini, adakah guru-guru sudah bersedia untuk menerapkan penggunaan teknologi maklumat sebagai kaedah pengajaran dan pembelajaran yang berkesan di dalam bilik darjah?

Tahap kesediaan guru dalam penggunaan teknologi maklumat berasaskan komputer merupakan salah satu aspek penting bagi menangani perubahan ke arah pengajaran dan pembelajaran sains yang berkesan. Penerapan mata pelajaran teknologi maklumat dalam sukatan pelajaran tertentu di peringkat sekolah ialah salah satu inisiatif bagi membolehkan guru-guru membiasakan diri dengan penggunaan teknologi maklumat serta meningkatkan kemahiran dalam bidang teknologi. Van Lengen dalam Morton (1996) menyatakan bahawa kebanyakan guru sudah bersedia untuk mengimplementasikan teknologi dalam pengajaran dan pembelajaran mereka tetapi apa yang menjadi masalah utamanya ialah mereka tidak tahu bagaimana untuk menggunakan komputer dalam proses pengajaran dan pembelajaran. Kesediaan guru dalam penggunaan teknologi maklumat merupakan kayu pengukur untuk melihat 
sejauh mana pemahaman guru tentang teknologi baru serta mengetahui segala kemahiran yang diperolehi hasil daripada menghadiri kursus-kursus teknologi yang terkini. Kajian Norizan (2002) yang melihat kesediaan guru bahasa dalam penggunaan komputer mendapati guru-guru lebih mengetahui tentang komputer dan bukannya kebolehan menggunakan komputer. Kesediaan guru merupakan salah satu elemen penting serta dapat memainkan peranan untuk membantu pelajar menyesuaikan diri dalam suasana dan kaedah pembelajaran yang baru serta didedahkan dengan penggunaan teknologi yang baru. Sekiranya guru tidak bersedia, maka segala program yang akan dijalankan oleh pihak Kementerian Pelajaran yang melibatkan teknologi baru seperti pelaksanaan sekolah bestari dan English for Teaching Mathematic and Science (Etems) tidak akan dapat dijayakan dengan berkesan.

Dalam kajian ini, teknologi maklumat didefinisikan sebagai satu bahan pengantara bagi membekalkan dan menyampaikan maklumat yang melibatkan penggunaan dan pemprosesan. Dalam kajian ini, penggunaan teknologi maklumat adalah berasaskan kepada dua faktor utama iaitu komputer dan internet. Ini termasuklah apa yang terlibat dalam pengajaran dan pembelajaran mengikut kajian Johnson (1998) iaitu:

(i) penggunaan asas operasi komputer,

(ii) pengurusan fail,

(iii) pemprosesan perkataan,

(iv) penggunaan hamparan elektronik,

(v) penggunaan pangkalan data,

(vi) penggunaan grafik,

(vii) penggunaan internet,

(viii) penggunaan e-mel,

(ix) kefahaman etika pengguna,

(x) persembahan elektronik,

(xi) pengintergrasian teknologi,

(xii) perisian,

(xiii) literasi maklumat

(xiv) world wide web,

(xv) pembinaan laman web,

(xvi) hipermedia,

(xvii) rangkaian, dan

(xviii) pencarian maklumat.

Banyak kajian telah dijalankan terhadap kesediaan guru dalam penggunaan komputer tetapi tidak banyak kajian yang telah dijalankan terhadap kesediaan guru dalam penggunaan teknologi maklumat. Antaranya ialah kajian kesediaan guru kemahiran hidup oleh Musa (1999) menunjukkan bahawa tidak semua guru sudah bersedia menggunakan komputer. Halim (2000) juga mendapati bahawa di kalangan guru-guru sekolah rendah masih belum bersedia menggunakan komputer. Beliau melihat kesediaan guru dalam penggunaan komputer di kalangan guru-guru di sekolah rendah di daerah Kota Setar dan mendapati guru-guru tersebut tidak begitu bersedia dalam penggunaan komputer. Kajian oleh Badrul Hisham (1998) ke atas kesediaan guru-guru matematik di sekolah menengah dalam kaedah pengajaran dan pembelajaran berbantukan komputer (PPBK) mendapati guru-guru kurang didedahkan dengan penggunaan komputer. Walau bagaimanapun, kebanyakan mereka mempunyai sikap yang positif terhadap penggunaan komputer dalam membantu tugas 
harian mereka. Nadarajan (2002) melaporkan tentang penggunaan teknologi maklumat dalam pengajaran dan pembelajaran mata pelajaran ekonomi. Hasil menunjukkan bahawa secara keseluruhan tahap penggunaan teknologi maklumat di kalangan guruguru ekonomi adalah sederhana.

Namun demikian, sehingga kini penggunaan teknologi maklumat belum lagi diimplementasikan secara menyeluruh dari segi amalannya dalam proses pengajaran dan pembelajaran di sekolah-sekolah. Satu kajian yang komprehensif perlu dijalankan agar penggunaan teknologi maklumat ini mendapat manfaat serta tidak membazirkan masa sebelum diterapkan dalam pengajaran dan pembelajaran terutamanya bagi mata pelajaran sains. Persoalannya di sini adalah untuk menentukan sama ada guruguru sudah bersedia untuk mengimplementasikan teknologi maklumat ini dalam pengajaran dan pembelajaran sains di dalam bilik darjah, ataupun tidak.

\subsection{TUJUAN DAN OBJEKTIF KAJIAN}

Kajian ini bertujuan untuk melihat tahap kesediaan guru dalam penggunaan teknologi maklumat berasaskan komputer bagi pengajaran dan pembelajaran sains. Kajian ini menumpukan kepada aspek tahap kesediaan dari segi pengetahuan dan sikap guru dalam pengajaran dan pembelajaran sains. Objektif kajian adalah seperti yang berikut:

(a) Mendapatkan maklumat latar belakang guru dalam penggunaan teknologi maklumat di dalam pengajaran dan pembelajaran sains.

(b) Menentukan tahap kesediaan guru sains dari segi penggunaan teknologi maklumat di dalam pengajaran dan pembelajaran sains berdasarkan kepada aspek pengetahuan dan sikap.

(c) Menentukan sama ada terdapat perbezaan yang signifikan dari segi tahap kesediaan guru sains bagi aspek pengetahuan dan sikap mengikut jantina.

(d) Menentukan sama ada terdapat perbezaan yang signifikan dari segi tahap kesediaan guru sains bagi aspek pengetahuan dan sikap mengikut kumpulan perkhidmatan guru.

\subsection{KAEDAH KAJIAN}

Kajian yang dijalankan ini berbentuk kajian tinjauan apabila reka bentuk kajian ini ialah secara deskriptif dan kuantitatif. Tahap kesediaan dilihat pada aspek sejauh mana perlengkapan guru dari segi pengetahuan dan sikap. Data dikumpul daripada 22 buah sekolah menengah kebangsaan di daerah Hulu Langat. Bilangan sebenar sampel dibuat berdasarkan kepada bilangan guru sains yang terdapat di sekitar sekolah menengah kebangsaan di daerah tersebut. Bilangan responden ialah seramai 223 orang guru iaitu $82.6 \%$ daripada populasi yang berjumlah 270 orang. Kajian ini menggunakan soal selidik sebagai alat pengukur. Soal selidik ini dibahagikan kepada dua iaitu 
Bahagian A yang menerangkan tentang demografi responden iaitu jantina, umur, kumpulan perkhidmatan, pengalaman mengajar, mata pelajaran pengkhususan, pengalaman dan kemudahan menggunakan komputer, pengalaman dan kemudahan menggunakan Internet serta keperluan menggunakan jenis-jenis teknologi maklumat yang tertentu dalam pengajaran. Bahagian B pula menjurus kepada set soal selidik 'The Technology in My Life Survey' yang dijalankan oleh McKenzie pada tahun 1999. Berpandukan kepada soal selidik tersebut, penyelidik telah mengubah suai dan menterjemahkan mengikut persoalan kajian penyelidik. Soal selidik ini terdiri daripada 10 item yang menggambarkan mengenai tahap kesediaan dari aspek pengetahuan dan 12 item yang menggambarkan mengenai tahap kesediaan dari aspek sikap. Kesemua maklum balas tiap-tiap item menggambarkan kesediaan guru-guru tersebut mengikut skala Likert lima mata dengan skor 1, 2, 3, 4 dan 5 bagi pengetahuan dan sikap yang positif. Data yang dikumpul dianalisis secara deskriptif dengan melihat taburan kekerapan, min dan sisihan piawai serta analisis inferens iaitu ujian-t.

\subsection{HASIL KAJIAN}

Seramai 223 orang guru telah menghantar semula borang soal selidik yang telah dilengkapkan. Daripada jumlah tersebut 31 orang guru terdiri daripada guru lelaki manakala 192 orang guru perempuan.

Bilangan guru siswazah yang terlibat ialah seramai 202 iaitu sebanyak 90.6\% berbanding 21 orang guru bukan siswazah iaitu 9.4\%.

Merujuk pada Jadual 1, guru sains yang terlibat dalam kajian terdiri daripada guru fizik iaitu seramai 34 orang (15.2\%), guru kimia iaitu seramai 45 orang (20.2\%), guru biologi iaitu seramai 60 orang (26.9\%), guru sains iaitu seramai 71 orang (31.8\%) dan bakinya ialah guru yang mempunyai pengkhususan yang lain seperti sains pertanian, matematik iaitu seramai 13 orang (5.8\%).

Dari segi pengalaman menggunakan komputer (Jadual 2), bilangan yang tidak pernah menggunakannya ialah seramai 22 orang iaitu 9.9\%. Bilangan ini agak kecil jika dibandingkan dengan yang lain-lain. Kebanyakannya mengatakan pernah menggunakan komputer atau telahpun mendapat pendedahan mengenai komputer sama ada di sekolah atau di rumah masing-masing. Bilangan yang mendapat kemudahan di sekolah ialah seramai 206 orang yang mewakili 92.4\% dan yang di rumah iaitu

Jadual 1 Kekerapan dan peratusan - Pengkhususan

\begin{tabular}{lccc}
\hline Perkara & Latar belakang & Bilangan & Peratus \\
\hline & Fizik & 34 & $15.2 \%$ \\
Pengkhususan & Kimia & 45 & $20.2 \%$ \\
& Biologi & 60 & $26.9 \%$ \\
& Sains & 71 & $31.8 \%$ \\
& Lain-lain & 13 & $5.8 \%$ \\
\hline
\end{tabular}


Jadual 2 Kekerapan dan peratusan - Pengalaman dan kemudahan menggunakan komputer

\begin{tabular}{lccc}
\hline Perkara & Latar belakang & Bilangan & Peratus \\
\hline Pengalaman menggunakan & Tidak pernah & 22 & $9.9 \%$ \\
komputer & $<2$ tahun & 53 & $23.8 \%$ \\
& $3-4$ tahun & 51 & $22.9 \%$ \\
& $5-6$ tahun & 53 & $23.8 \%$ \\
Kemudahan komputer di sekolah & $>7$ tahun & 44 & $19.7 \%$ \\
& Ya & 206 & $92.4 \%$ \\
Kemudahan komputer di rumah & Tidak & 17 & $7.6 \%$ \\
& Ya & 201 & $90.1 \%$ \\
& Tidak & 22 & $9.9 \%$ \\
\hline
\end{tabular}

seramai 201 orang yang mewakili 90.1\% responden. Didapati juga hanya 22 orang guru sains sahaja iaitu 9.9\% yang tidak mempunyai kemudahan komputer di rumah.

Dari segi pengalaman menggunakan internet pula (Jadual 3), kebanyakan responden baru mula mempelajari internet kurang daripada 2 tahun. Terdapat juga responden yang langsung tidak mempunyai pengalaman menggunakan internet iaitu seramai 70 orang (31.4\%). Jumlah ini agak besar jika dibandingkan dengan keseluruhan bilangan responden. Ini menunjukkan bahawa ramai guru-guru sains masih belum menyedari kepentingan penggunaan internet untuk mendapatkan maklumat yang terkini di zaman teknologi maklumat ini. Dari jadual ini juga, ia menunjukkan masih ramai guru sains yang tidak mempunyai kemudahan internet sama ada di rumah iaitu seramai 90 orang (40.4\%) ataupun di sekolah iaitu seramai 113 orang (50.6\%).

Dapatan kajian mengenai keperluan menerapkan penggunaan jenis-jenis teknologi maklumat yang tertentu dalam pengajaran dan pembelajaran sains adalah seperti dalam Jadual 6. Daripada jadual tersebut,dapat dirumuskan bahawa kebanyakan guru sains menyokong keperluan penggunaan teknologi maklumat untuk disampaikan kepada pelajar-pelajar melalui pengajaran dan pembelajaran. Antara jenis teknologi maklumat yang perlu diterapkan adalah seperti dalam Jadual 4:

Jadual 3 Kekerapan dan peratusan - Pengalaman dan kemudahan menggunakan internet

\begin{tabular}{lccc}
\hline Perkara & Latar belakang & Bilangan & Peratus \\
\hline Pengalaman menggunakan internet & Tidak pernah & 70 & $31.4 \%$ \\
& $<2$ tahun & 92 & $41.3 \%$ \\
& $3-4$ tahun & 38 & $17.0 \%$ \\
& $5-6$ tahun & 15 & $6.7 \%$ \\
Kemudahan internet di sekolah & $>7$ tahun & 8 & $3.6 \%$ \\
& Ya & 110 & $49.3 \%$ \\
Kemudahan internet di rumah & Tidak & 113 & $50.6 \%$ \\
& Ya & 133 & $59.6 \%$ \\
& Tidak & 90 & $40.4 \%$ \\
\hline
\end{tabular}


Jadual 4 Kekerapan dan peratusan - Keperluan menggunakan jenis-jenis teknologi maklumat di dalam pengajaran dan pembelajaran sains

\begin{tabular}{clc}
\hline Bil & Perkara & Perlu \\
\hline 1. & Asas Operasi Komputer & $197(88.3 \%)$ \\
2. & Pengurusan Fail & $185(83.0 \%)$ \\
3. & Pemprosesan Perkataan & $182(81.6 \%)$ \\
4. & Hamparan Elektronik & $145(65.0 \%)$ \\
5. & Pangkalan Data & $157(70.4 \%)$ \\
6. & Grafik & $182(81.6 \%)$ \\
7. & Internet & $199(89.2 \%)$ \\
8. & E-mail & $155(69.5 \%)$ \\
9. & Etika Penggunaan & $150(67.3 \%)$ \\
10. & Persembahan Elektronik & $163(73.1 \%)$ \\
11. & Pengintergrasian Teknologi & $150(67.3 \%)$ \\
12. & Perisian & $153(68.8 \%)$ \\
13. & Literasi Maklumat & $161(72.2 \%)$ \\
14. & World Wide Web & $159(71.3 \%)$ \\
15. & Pembinaan Laman Web & $135(60.5 \%)$ \\
16. & Hipermedia & $123(55.2 \%)$ \\
17. & Rangkaian & $136(61.0 \%)$ \\
18. & Pencarian Maklumat & $199(89.2 \%)$ \\
\hline
\end{tabular}

\subsection{Tahap Kesediaan Guru}

Kesediaan guru-guru dalam penggunaan teknologi maklumat amat penting bagi membantu negara membentuk masyarakat saintifik dan progresif dalam menyahut cabaran Wawasan 2020 yang ke-enam. Jadual 5 membentangkan kesediaan guru dari aspek pengetahuan.

\subsubsection{Kesediaan Guru Dari Aspek Pengetahuan}

Dari Jadual 5, didapati $44.8 \%$ daripada responden tahu menggunakan komputer dengan yakin. Seramai $32.7 \%$ pula telah mendapat pendedahan tentang komputer dan boleh menggunakannya. Hanya 18 orang iaitu $8.1 \%$ yang tidak tahu menggunakan komputer mahupun mengetahui asas pengkomputeran. Item pengetahuan yang pertama ini menunjukkan bahawa kebanyakan responden sudah mengetahui asas menggunakan komputer.

Item kelima adalah untuk mendapat maklum balas sama ada responden sudah bersedia untuk menjalankan demonstrasi menggunakan teknologi baru ini. Hasil yang didapati ialah kebanyakan responden tidak yakin dengan kebolehan mereka untuk membuat demonstrasi menggunakan teknologi maklumat. Bilangan responden yang menjawab sangat tidak setuju, tidak setuju dan kurang setuju ialah seramai 176 orang (79\%). Kebanyakan responden masih belum bersedia mereka bentuk aktiviti 
Jadual 5 Kekerapan dan peratusan - Aspek pengetahuan

\begin{tabular}{|c|c|c|c|c|c|c|}
\hline Bil. & Item & STS & TS & $\mathbf{K S}$ & $\mathbf{S}$ & SS \\
\hline \multirow[t]{2}{*}{1} & Menggunakan dan tahu asas komputer & 4 & 14 & 32 & 73 & 100 \\
\hline & dengan yakin & $1.8 \%$ & $6.3 \%$ & $14.3 \%$ & $32.7 \%$ & $44.8 \%$ \\
\hline \multirow[t]{2}{*}{2} & Boleh menilai teknologi maklumat dan & 10 & 31 & 47 & 107 & 28 \\
\hline & mempelbagaikan aktiviti P-P di dalam kelas & $4.5 \%$ & $13.9 \%$ & $21.1 \%$ & $48.0 \%$ & $12.6 \%$ \\
\hline \multirow[t]{2}{*}{3} & Mampu mencari peluang untuk & 6 & 27 & 79 & 85 & 26 \\
\hline & meningkatkan pengetahuan dan kemahiran & $2.7 \%$ & $12.1 \%$ & $35.4 \%$ & $38.1 \%$ & $11.7 \%$ \\
\hline \multirow[t]{2}{*}{4} & Boleh mengenal pasti perkaitan antara & 9 & 27 & 74 & 95 & 18 \\
\hline & $\begin{array}{l}\text { kemahiran mencari maklumat dengan } \\
\text { objektif kurikulum }\end{array}$ & $4.0 \%$ & $12.1 \%$ & $33.2 \%$ & $42.6 \%$ & $8.1 \%$ \\
\hline \multirow[t]{2}{*}{5} & Boleh membuat demonstrasi menggunakan & 31 & 63 & 82 & 35 & 12 \\
\hline & teknologi baru & $13.9 \%$ & $28.3 \%$ & $36.8 \%$ & $15.7 \%$ & $5.4 \%$ \\
\hline \multirow[t]{2}{*}{6} & Boleh mereka bentuk aktiviti pembelajaran & 37 & 60 & 78 & 39 & 9 \\
\hline & $\begin{array}{l}\text { dengan mengintegrasikan teknologi } \\
\text { maklumat }\end{array}$ & $16.6 \%$ & $26.9 \%$ & $35.0 \%$ & $17.5 \%$ & $4.0 \%$ \\
\hline \multirow[t]{2}{*}{7} & Mahir menggunakan perisian & 33 & 49 & 81 & 45 & 15 \\
\hline & & $14.8 \%$ & $22.0 \%$ & $36.3 \%$ & $20.2 \%$ & $6.7 \%$ \\
\hline \multirow[t]{2}{*}{8} & Memahami aspek-aspek etika yang & 19 & 49 & 77 & 65 & 13 \\
\hline & berkaitan teknologi maklumat & $8.5 \%$ & $22.0 \%$ & $34.5 \%$ & $29.1 \%$ & $5.8 \%$ \\
\hline \multirow[t]{2}{*}{9} & Boleh mempelbagaikan strategi & 12 & 38 & 99 & 61 & 13 \\
\hline & $\begin{array}{l}\text { penggunaan teknologi maklumat untuk } \\
\text { menggalakkan proses P-P }\end{array}$ & $5.4 \%$ & $17.0 \%$ & $44.4 \%$ & $27.4 \%$ & $5.8 \%$ \\
\hline \multirow[t]{2}{*}{10} & Boleh meningkatkan kemahiran membuat & 13 & 37 & 72 & 86 & 15 \\
\hline & $\begin{array}{l}\text { jangkaan, interpretasi dan sintesis kepada } \\
\text { pelajar }\end{array}$ & $5.8 \%$ & $16.6 \%$ & $32.2 \%$ & $38.6 \%$ & $6.7 \%$ \\
\hline
\end{tabular}

pembelajaran dengan menggunakan intergrasi teknologi maklumat. Ini ditunjukkan dengan maklum balas responden yang sangat tidak setuju, tidak setuju dan kurang setuju dengan kenyataan item ini iaitu seramai 175 orang (78.5\%). Terdapat juga responden yang sudah tahu mereka bentuk aktiviti pembelajaran dengan menggunakan teknologi maklumat iaitu seramai 48 orang (21.5\%).

Bilangan responden yang mahir menggunakan perisian ialah seramai 60 orang sahaja yang mewakili $26.9 \%$. Responden yang lain menunjukkan mereka belum bersedia menggunakan perisian dalam pengajaran dan pembelajaran. Etika penggunaan amat penting dalam menerapkan teknologi maklumat dalam pengajaran dan pembelajaran. Hanya 78 orang $(34.9 \%)$ sahaja yang betul-betul memahami aspek etika dalam penggunaan manakala baki responden yang lain masih belum memahaminya.

Kemungkinan disebabkan oleh kurang pendedahan tentang teknologi maklumat maka ramai responden yang belum bersedia mempelbagaikan strategi penggunaan teknologi maklumat untuk menggalakkan proses pengajaran dan pembelajaran. Ini dapat dilihat daripada jumlah yang kurang bersetuju,tidak bersetuju dan sangat tidak bersetuju dengan item ini iaitu seramai 149 orang yang merupakan 66.8\% daripada 
keseluruhan jumlah responden. Hanya 74 orang (33.2\%) yang sudah bersedia untuk mempelbagaikan strategi pengajaran mereka.

Min keseluruhan bagi bahagian pengetahuan guru ialah 3.2 dengan sisihan piawainya ialah 0.7844 dalam bentuk taburan normal. Ini menunjukkan bahawa tahap kesediaan guru dalam penggunaan teknologi bagi pengajaran dan pembelajaran sains adalah pada tahap sederhana. Dari sisihan piawai pula, menunjukkan taburan kurang tersebar, dan kebanyakannya tertumpu pada nilai min. Sebagai rumusannya, tahap kesediaan responden bagi aspek pengetahuan tentang teknologi maklumat adalah pada aras sederhana. Ini menunjukkan bahawa kebanyakan responden telah mendapat pendedahan awal tentang kegunaan teknologi maklumat serta kepentingannya dalam pendidikan.

\subsubsection{Kesediaan Guru Dari Aspek Sikap}

Dari Jadual 6, didapati seramai 149 orang (66.8\%) responden mengatakan bahawa teknologi maklumat mudah dipelajari. Dari segi sikap, guru-guru ini tidak menghadapi

Jadual 6 Kekerapan, peratusan dan min - Aspek sikap

\begin{tabular}{|c|c|c|c|c|c|c|}
\hline Bil. & Item & STS & TS & $\mathbf{K S}$ & $\mathbf{S}$ & SS \\
\hline \multirow[t]{2}{*}{1} & Teknologi maklumat mudah dipelajari & 2 & 16 & 56 & 103 & 46 \\
\hline & dan berminat untuk mempelajari lagi & $0.9 \%$ & $7.2 \%$ & $25.1 \%$ & $46.2 \%$ & $20.6 \%$ \\
\hline \multirow[t]{2}{*}{2.} & Dapat memperbaiki cara pengajaran saya & 3 & 19 & 66 & 108 & 27 \\
\hline & & $1.3 \%$ & $8.5 \%$ & $29.6 \%$ & $48.4 \%$ & $12.1 \%$ \\
\hline \multirow[t]{2}{*}{3.} & Akan memperkenalkannya di dalam bilik & 10 & 60 & 93 & 53 & 7 \\
\hline & darjah & $4.5 \%$ & $26.9 \%$ & $41.7 \%$ & $23.8 \%$ & $3.1 \%$ \\
\hline \multirow[t]{2}{*}{4.} & Perubahan berlaku dengan cepat sehingga & 7 & 24 & 59 & 90 & 43 \\
\hline & tidak cukup perancangan untuk bantu guru & $3.1 \%$ & $10.8 \%$ & $26.5 \%$ & $40.4 \%$ & $19.3 \%$ \\
\hline \multirow[t]{2}{*}{5.} & Rakan membesarkan isu remeh tentang & 34 & 54 & 93 & 36 & 6 \\
\hline & teknologi maklumat & $15.2 \%$ & $24.2 \%$ & $41.7 \%$ & $16.1 \%$ & $2.7 \%$ \\
\hline \multirow[t]{2}{*}{6.} & Telah menggunakan sepenuhnya di dalam & 69 & 66 & 71 & 13 & 4 \\
\hline & bilik darjah & $30.9 \%$ & $29.6 \%$ & $31.8 \%$ & $5.8 \%$ & $1.8 \%$ \\
\hline \multirow[t]{2}{*}{7.} & Menggalakkan menukar cara pengajaran & 15 & 55 & 67 & 75 & 11 \\
\hline & dan perhubungan dengan pelajar & $6.7 \%$ & $24.7 \%$ & $30.0 \%$ & $33.6 \%$ & $4.9 \%$ \\
\hline \multirow[t]{2}{*}{8.} & Merasa lebih seronok mengajar & 24 & 44 & 80 & 63 & 12 \\
\hline & & $10.8 \%$ & $19.7 \%$ & $35.9 \%$ & $28.3 \%$ & $5.4 \%$ \\
\hline \multirow[t]{2}{*}{9.} & Bangga dengan pencapaian walaupun & 7 & 37 & 56 & 104 & 19 \\
\hline & banyak yang perlu dipelajari & $3.1 \%$ & $16.6 \%$ & $25.1 \%$ & $46.6 \%$ & $8.5 \%$ \\
\hline \multirow[t]{2}{*}{10.} & Seronok bekerja bersama rakan dalam & 12 & 52 & 64 & 82 & 13 \\
\hline & $\begin{array}{l}\text { menyediakan rancangan pelajaran } \\
\text { menggunakan teknologi maklumat }\end{array}$ & $5.4 \%$ & $23.3 \%$ & $28.7 \%$ & $36.8 \%$ & $5.8 \%$ \\
\hline \multirow[t]{2}{*}{11.} & Lebih menghargai buku kerana dapat & 9 & 24 & 52 & 114 & 24 \\
\hline & banyak maklumat baru & $4.0 \%$ & $10.8 \%$ & $23.3 \%$ & $51.1 \%$ & $10.8 \%$ \\
\hline \multirow[t]{2}{*}{12.} & Bersedia untuk menghadapi cabaran baru & 1 & 12 & 33 & 138 & 39 \\
\hline & berkaitan dengan teknologi maklumat & $0.4 \%$ & $5.4 \%$ & $14.8 \%$ & $61.9 \%$ & $17.5 \%$ \\
\hline
\end{tabular}


masalah untuk mempelajari teknologi maklumat dan mereka berminat untuk mempelajarinya lagi. Sungguhpun begitu terdapat 74 orang (33.2\%) yang tidak bersetuju dengan item tersebut termasuklah mereka yang kurang bersetuju. Item kedua pula bertujuan untuk melihat sama ada teknologi maklumat dapat memperbaiki cara pengajaran responden. Maklum balas mendapati bahawa 135 orang (60.5\%) responden bersetuju dengan item tersebut. Seramai 66 orang responden (29.6\%) kurang bersetuju, manakala 22 orang (9.8\%) tidak bersetuju dengan kenyataan tersebut. Ini menunjukkan bahawa masih terdapat guru yang tidak dapat menerima pembaharuan dalam bidang pendidikan iaitu dari segi penggunaan teknologi maklumat untuk memperbaiki pengajaran mereka.

Berdasarkan maklum balas responden, item ketiga pula menunjukkan bahawa guruguru masih belum begitu berminat untuk memperkenalkan teknologi maklumat dalam pengajaran dan pembelajaran mereka. Ini ditunjukkan dengan peratusan yang tinggi bagi mereka yang sangat tidak bersetuju, tidak bersetuju dan kurang bersetuju iaitu seramai 163 orang (73.1\%).

Perubahan dalam teknologi maklmuat dikatakan berlaku dengan begitu cepat sehingga tidak cukup perancangan untuk membantu guru-guru. Ini amat disetujui oleh sebilangan besar responden iaitu seramai 133 orang $(59.7 \%)$.

Dari segi penggunaan teknologi maklumat di dalam bilik darjah, didapati lebih daripada separuh responden iaitu 135 orang (60.5\%) tidak bersetuju mereka telah menggunakan sepenuhnya teknologi maklumat di dalam bilik darjah. Begitu juga seramai 71 orang (31.8\%) yang kurang bersetuju dengan item ini manakala bilangan responden yang bersetuju dengan item enam ini adalah sangat kecil iaitu 17 orang (7.6\%) sahaja. Dapatan ini penting bagi menggambarkan penggunaan sebenar teknologi maklumat semasa proses pengajaran dan pembelajaran oleh guru-guru sains.

Item yang ketujuh menyatakan sama ada penggunaan teknologi maklumat ini dapat menggalakkan responden menukar cara pengajaran serta perhubungan dengan pelajar. Maklum balas yang diterima ialah seramai 86 orang (38.5\%) bersetuju dengan kenyataan tersebut. Terdapat juga yang kurang bersetuju iaitu seramai 67 orang (30.0\%) manakala yang tidak bersetuju ialah seramai 70 orang (31.4\%). Dari maklumat ini, dapat dirumuskan bahawa terdapat tiga kumpulan guru sains yang mempunyai pandangan yang berbeza terhadap penggunaan teknologi maklumat dalam pengajaran dan pembelajaran. Kumpulan yang pertama, yang bersetuju menggunakan teknologi maklumat dan mempraktikkannya di sekolah-sekolah. Kumpulan ini akan mengikuti perubahan yang berlaku dan dapat mempelbagaikan cara pengajaran. Bagi kumpulan yang kedua pula, jawapan kurang setuju menunjukkan sikap yang tidak menggalakkan penggunaan teknologi maklumat. Bagi kumpulan yang tidak bersetuju langsung, menunjukkan mereka memang tidak mahu memberi sokongan atau mengubah cara pengajaran mereka yang diamalkan selama ini.

Sebahagian responden menyatakan rasa seronok mengajar menggunakan teknologi maklumat ini iaitu seramai 75 orang (33.7\%) manakala 80 orang (35.9\%) kurang 
bersetuju dan 68 orang (30.5\%) pula tidak seronok. Kesediaan guru-guru dari segi sikap perlu diperbaiki sebelum dapat diterapkan penggunaan teknologi baru ini. Untuk menarik minat pelajar di dalam kelas, keseronokan untuk mengajar dan belajar perlu ada.

Item sebelas mencerminkan keutamaan responden dalam proses pengajaran dan pembelajaran di mana kebanyakan responden lebih menghargai buku kerana dapat banyak maklumat baru iaitu seramai 138 orang (61.9\%). Sikap ini menunjukkan responden bersedia dari segi sikap untuk memperbaiki diri dan mendapatkan maklumat dari pembacaan buku-buku rujukan yang banyak terdapat di pasaran berbanding dari penggunaan teknologi maklumat.

Min keseluruhan bagi aspek sikap ialah 3.24 manakala sisihan piawai ialah 0.62 . Min ini menunjukkan tahap kesediaan dalam penggunaan teknologi maklumat dari aspek sikap ialah pada tahap sederhana. Walau bagaimanapun, dari sisihan piawai didapati ia lebih tertumpu dan tidak tersebar dengan begitu meluas. Sebagai rumusan terhadap tahap kesediaan dari aspek sikap, didapati secara keseluruhannya responden menunjukkan sikap yang positif terhadap penggunaan teknologi maklumat. Ini berdasarkan nilai min bagi aspek sikap kebanyakannya berada pada aras sederhana. Hanya item enam sahaja yang menunjukkan aras rendah, iaitu guru-guru masih belum menggunakan teknologi sepenuhnya di dalam bilik darjah.

\subsection{Perbezaan Min Tahap Kesediaan Mengikut Jantina}

Kajian ini juga ingin melihat adakah terdapat perbezaan yang signifikan dari segi tahap kesediaan guru sains dari segi penggunaan teknologi maklumat dalam pengajaran dan pembelajaran berdasarkan jantina?

\subsubsection{Aspek Pengetahuan}

Hasil analisis ujian- $t$ untuk melihat terdapatnya perbezaan min di antara tahap kesediaan penggunaan teknologi maklumat dari aspek pengetahuan mengikut jantina guru ditunjukkan dalam Jadual 7.

Berdasarkan Jadual 7, nilai $t$ bagi jantina ialah $t=1.660$ dan kesignifikanan 2-hujung ialah 0.098 adalah signifikan pada tahap $p<0.05$. Ini bermaksud tidak terdapat perbezaan yang signifikan terhadap jantina guru dari segi tahap kesediaan penggunaan

Jadual 7 Perbezaan min tahap kesediaan pengetahuan berdasarkan jantina guru

\begin{tabular}{lcccccc}
\hline Jantina & $\mathbf{n}$ & Min & s.p & d.k. & t & p \\
\hline Lelaki & 31 & 3.4161 & 0.8017 & & & \\
Perempuan & 192 & 3.1651 & 0.7781 & & & \\
\hline
\end{tabular}

Signifikan pada tahap $p<0.05$ 
teknologi maklumat dalam pengajaran dan pembelajaran sains berdasarkan pengetahuan.

\subsubsection{Aspek Sikap}

Hasil analisis ujian- $t$ untuk melihat sama ada terdapat perbezaan min antara tahap kesediaan penggunaan teknologi maklumat dari aspek sikap responden mengikut jantina guru seperti dalam Jadual 8.

Jadual 8 Perbezaan min tahap kesediaan sikap berdasarkan jantina guru

\begin{tabular}{lcccccc}
\hline Jantina & $\boldsymbol{n}$ & Min & s.p & d.k. & $\boldsymbol{t}$ & $\boldsymbol{p}$ \\
\hline Lelaki & 31 & 3.3845 & 0.6601 & & & \\
Perempuan & 192 & 3.2115 & 0.6130 & & & \\
\hline
\end{tabular}

Signifikan pada tahap $p<0.05$

Jadual tersebut di atas menunjukkan bahawa nilai $t$ bagi jantina ialah $t=1.443$ dan kesignifikanan 2-hujung ialah 0.150 adalah signifikan pada tahap $p<0.05$. Ini bermaksud tidak terdapat perbezaan yang signifikan terhadap jantina guru dari segi tahap kesediaan penggunaan teknologi maklumat dalam pengajaran dan pembelajaran sains berdasarkan sikap.

\subsection{Perbezaan Min Tahap Kesediaan Mengikut Kumpulan Perkhimatan}

\subsubsection{Aspek Pengetahuan}

Hasil analisis ujian- $t$, untuk melihat sama ada terdapat perbezaan min antara tahap kesediaan dari aspek pengetahuan mengikut kumpulan perkhidmatan guru dalam Jadual 9.

Dari Jadual 9, nilai $t$ bagi kumpulan perkhidmatan ialah $t=1.613$ dan kesignifikanan 2-hujung ialah 0.108 adalah signifikan pada tahap $p<0.05$. Ini bermaksud tidak terdapat perbezaan yang signifikan terhadap kumpulan perkhidmatan dari segi tahap kesediaan

Jadual 9 Perbezaan min tahap kesediaan pengetahuan berdasarkan kumpulan perkhidmatan

\begin{tabular}{lcccccc}
\hline Kumpulan perkhidmatan & $\mathbf{n}$ & Min & s.p & d.k. & $\boldsymbol{t}$ & $\boldsymbol{p}$ \\
\hline Siswazah & 202 & 3.2272 & 0.7782 & & & \\
Bukan siswazah & 21 & 2.9381 & 0.8145 & & & \\
\hline
\end{tabular}

Signifikan pada tahap $p<0.05$ 
penggunaan teknologi maklumat dalam pengajaran dan pembelajaran sains berdasarkan pengetahuan.

\subsubsection{Aspek Sikap}

Jadual 10 menunjukkan hasil analisis yang telah dijalankan untuk melihat sama ada terdapat perbezaan min di antara tahap kesediaan penggunaan teknologi maklumat dari aspek sikap mengikut kumpulan perkhidmatan guru.

Dari analisis yang telah dijalankan, nilai $t$ bagi kumpulan perkhidmatan ialah $t=1.788$ dan kesignifikanan 2-hujung ialah 0.076 adalah signifikan pada tahap $p<0.05$. Ini bermaksud tidak terdapat perbezaan yang signifikan terhadap kumpulan perkhidmatan dari segi penggunaan teknologi maklumat dalam pengajaran dan pembelajaran sains berdasarkan sikap.

Jadual 10 Perbezaan min tahap kesediaan sikap berdasarkan kumpulan perkhidmatan

\begin{tabular}{llccccc}
\hline Kumpulan Perkhidmatan & n & Min & s.p & d.k. & $\boldsymbol{t}$ & $\boldsymbol{p}$ \\
\hline Siswazah & 202 & 3.2593 & 0.6100 & & & \\
Bukan Siswazah & 21 & 3.0067 & 0.6947 & & & \\
\hline
\end{tabular}

Signifikan pada tahap $p<0.05$

\subsection{PERBINCANGAN}

\subsection{Pengalaman Menggunakan Komputer dan Internet}

Hasil kajian yang dijalankan menunjukkan bahawa kebanyakan guru-guru sains sudah mempunyai pengalaman menggunakan komputer sama ada di rumah atau di sekolah iaitu seramai lebih kurang 90.2\% (201 orang) daripada jumlah responden. Hanya lebih kurang 9.9\% (22 orang) sahaja yang tidak pernah menggunakan komputer. Kebanyakan daripada guru-guru ini mendapat kemudahan sama ada di sekolah 92.4\% (206 orang) atau di rumah 90.1\% (201 orang) mereka sendiri. Kenyataan ini menyokong kajian yang dijalankan oleh Germann \& Barrow (1996) yang mendapati bahawa kebanyakan guru sains di Missouri telah pun mempunyai pengalaman menggunakan komputer sama ada di rumah atau di sekolah sejak beberapa tahun yang lalu. Kajian oleh Becker, Ravitz \& Wong (1999) juga menyatakan hampir 80\% orang guru mempunyai sebuah komputer setiap seorang di rumah masing-masing. Selain daripada itu,didapati juga 93\% orang guru telah dan masih menggunakan komputer dalam bidang masingmasing.

Dari keputusan kajian ini, dapat dirumus bahawa kemudahan menggunakan komputer memang telah ada. Sungguhpun begitu, peluang untuk menggunakan komputer di sekolah mungkin agak terhad disebabkan oleh bilangan perkakasan yang tidak mencukupi, kekangan masa serta lain-lain masalah yang timbul. Bekalan 
komputer serta keperluan teknologi maklumat di sekolah-sekolah adalah terhad. Ini menyebabkan proses pengintergrasian menjadi lembab dan guru serta pelajar tidak berpeluang mencuba dan menggunakan teknologi ini dalam bilik darjah (Bosch dan Cardinale, 1993; Roszell 1995; Abdul Razak dan Jamaludin, 1998)

Keputusan ini juga menunjukkan bahawa guru-guru telah mempunyai serta berpengalaman menggunakan komputer, akan tetapi tujuan penggunaannya tidak dapat dikenalpasti. Kajian yang dijalankan oleh Abd. Razak \& Jamaludin (1998), mendapati guru-guru mempunyai pengalaman menggunakan komputer untuk keperluan diri sendiri seperti penulisan dan penyimpanan rekod tetapi bukan untuk pengajaran dan pembelajaran. Kajian ini juga menunjukkan bahawa tujuan guru-guru menggunakan komputer adalah pelbagai dan lebih kepada untuk memudahkan pengurusan harian. Dari segi kemudahan internet pula, seramai $31.4 \%$ (70 orang) daripada bilangan responden yang tidak mempunyai pengalaman menggunakan internet.

\subsection{Tahap Kesediaan}

Tahap kesediaan guru dari aspek pengetahuan adalah pada peringkat sederhana. Walaupun sebahagian guru tidak mengaplikasikan penggunaan teknologi maklumat ini dalam pengajaran dan pembelajaran, tetapi mereka tahu kegunaannya dalam membantu pengajaran di dalam kelas. Kebanyakan responden kajian telah mendapat pendedahan awal tentang kegunaan teknologi maklumat serta kepentingannya dalam pendidikan. Sikap merupakan satu lagi aspek kesediaan yang perlu diambil kira bagi menerapkan penggunaan teknologi maklumat dalam pengajaran dan pembelajaran sains. Pandangan yang berbeza-beza terhadap penggunaan teknologi maklumat ini secara tidak langsung memberi kesan kepada proses perubahan yang berlaku. Walau bagaimanapun, dari hasil analisis didapati guru-guru ini mempunyai sikap yang positif terhadap teknologi maklumat. Ini ditunjukkan dari nilai min keseluruhan dan sisihan piawai yang kebanyakannya tertumpu pada tahap sederhana hingga tinggi. Namun begitu, guru-guru sains perlu lebih bersedia untuk meningkatkan tahap penggunaan teknologi maklumat terutamanya dari aspek pengetahuan dan sikap. Ini memandangkan perubahan dalam teknologi maklumat berlaku dengan begitu pantas dan menyebabkan guru-guru yang tidak bersedia akan ketinggalan. Ini tidak seharusnya berlaku kerana guru merupakan barisan hadapan dalam menyampaikan maklumat kepada pelajar melalui pengajaran dan pembelajaran di sekolah. Oleh itu, para guru sepatutnya mengambil inisiatif sendiri untuk belajar dan mendalami teknologi maklumat. Sikap guru pula mestilah positif dan menerima teknologi maklumat sebagai satu faktor penting untuk membantu proses pengajaran dan pembelajaran serta meningkatkan kecemerlangan pelajar. Menurut Dias dan Atkinson (2001), sebelum guru dapat menerapkan penggunaan teknologi maklumat dalam bilik darjah, guru tersebut sendiri perlu bersikap positif dengan meningkatkan kemahiran diri yang ada agar proses pengajaran dan pembelajaran dapat berjalan lancar. 


\subsection{KESIMPULAN}

Kajian ini hanya dijalankan di daerah Hulu Langat dan hasil yang didapati menunjukkan bahawa kumpulan guru-guru ini sudah bersedia untuk menggunakan teknologi maklumat dalam pengajaran dan pembelajaran sains walaupun pada tahap yang sederhana bagi aspek pengetahuan dan sikap. Van Lengen dalam Morton (1996) menyatakan bahawa kebanyakan guru sudah bersedia untuk mengimplementasikan teknologi dalam pengajaran dan pembelajaran. Era teknologi ini berlaku dengan begitu pantas menyebabkan para guru yang tidak bersedia akan ketinggalan. Ini tidak seharusnya berlaku kerana guru merupakan elemen pertama dalam menyampaikan maklumat kepada pelajar menerusi pengajaran dan pembelajaran di sekolah. Oleh itu, para guru sepatutnya mengambil inisiatif sendiri untuk belajar dan mendalami bidang teknologi ini. Sikap guru juga mestilah positif dan menerima teknologi ini sebagai satu perubahan yang positif untuk kecemerlangan pelajar (Galigan, 1997). Guru juga harus memahirkan diri dengan berbagai kemahiran bukan sahaja untuk pengajaran dan pembelajaran malah untuk meningkatkan prestasi diri sendiri.

Guru-guru harus diberi peluang untuk mendalami penggunaan teknologi maklumat dalam pengajaran dan pembelajaran. Bilangan komputer yang mencukupi perlu dibekalkan untuk kegunaan guru dan pelajar. Selain itu, sebuah makmal komputer bersama keperluan rangkaian tertentu perlu disediakan untuk keselesaan guru dan pelajar. Pihak sekolah juga perlu menganjurkan kursus-kursus komputer dan penggunaan teknologi maklumat untuk guru dalam mempelbagaikan kaedah pengajaran di dalam kelas. Guru juga perlu didedahkan dengan cara membina dan membangunkan perisian agar guru mempunyai pengalaman untuk membuat bahan pengajaran sendiri mengikut kreativiti masing-masing. Selain daripada itu,cara membaiki komputer perlu didedahkan secara ringkas agar guru mempunyai pengalaman untuk membaiki komputer dan peralatan elektronik sekiranya ada kerosakan kecil.

Guru-guru juga mesti diberikan kebebasan untuk mempelbagaikan kaedah pengajaran dan pembelajaran di dalam kelas masing-masing. Kulik \& Kulik (1991) menyatakan keadaan ini akan membuatkan pengajaran dan pembelajaran menjadi lebih teratur. Ini disebabkan oleh pendekatan pembelajaran menggunakan teknologi ini lebih berpusatkan kepada pelajar dan ini memerlukan pelajar berbincang dan bertukar-tukar pendapat. Kelas akan menjadi lebih bising daripada biasa tetapi ia akan sentiasa di bawah kawalan seorang guru. Pelajar pula akan menjadi lebih kreatif dan aktif. Ini secara tidak langsung menjadikan suasana pembelajaran lebih selesa serta dapat menarik minat pelajar.

\section{RUJUKAN}

Abdul Razak Habib dan Jamaludin Badusah. 1998. Penggunaan Komputer Untuk Pengajaran dan Pembelajaran di Sekolah Menengah. Jurnal Pendidikan 23. (Atas talian). http://www.penerbit.ukm.my/jpend23-4.html (Dilayari pada 1 Februari 2002). 
Badrul Hisham Hj. Alang Osman. 1998. Kesediaan Guru Dalam Pengajaran dan Pembelajaran Matematik Berbantukan Komputer (PPBK) di Sekolah Menengah. (Atas talian). http://motivasiutusan.4mg.com/ kerja1.html (Dilayari pada 20 November 2000).

Ball, J. 1996. Technology Infusion Strategy. The Science Teacher. 639(3): 51-53.

Becker, H. J., J. L. Ravitz, dan Y. T. Wong. 1999. Teacher and Teacher - Directed Student Use of Computers and Software. (Atas talian ) http:/www.crito.uci.edu/tlc/findings/Computer Use/html/body_startpage.htm (Dilayari pada 12 Jun 2001).

Bosch, K. A. dan L. Cardinale. 1993. Preservice Teacher's Perceptions of Computer Use During a Field Experience. Journal of Computing in Teacher Education. 10(1): 23-27.

Chan Yuen Fook. 1999. Teknologi Maklumat dalam Pendidikan di Malaysia. Konvensyen Teknologi Pendidikan Ke-12. Port Dickson. PTPM.

Dias, L. B. dan S. Atkinson. 2001. Technology Intergration: Best Practices - Where Do Teachers Stand? International Electronic Journal for Leadershipin Learning. 5(10). (Atas talian). http://www.ucalgary.ca/ iejll/volume5/ dias.html (Dilayari pada 20 Julai 2001).

Galligan, J. 1997. Computers and Pedagogy: It's Not What You've Got, It's How You Use It. (Atas talian) http://www.woodvale.wa.edu.au/acec95 papers/volume1/paper7.Html (Dilayari pada 21 Jun 2001).

Germann, P. J. dan L. H. Barrow. 1996. The Use of Computer Technologies in Missouri Secondary Science Classrooms. Journal of Computer in Mathematics and Science Teaching. 15(3): 217-236

Halim Jajuli. 2000. Tahap Kesediaan Penggunaan Komputer di Kalangan Guru-guru Sekolah Rendah (Daerah Kota Setar). Latihan Ilmiah. Universiti Teknologi Malaysia.

Honey, M., K. McMillan, dan F. Craig. 1999. Perspectives on Technology and Education Research: Lessons from the Past and Present. (Atas talian) http://www.ed.gov/Technology/TechConf/1999/whitepapers/paper1.html (Dilayari pada 21 November 2000).

Jamaludin Badusah, Muhammad Hussin dan Abd. Rasid Johar. 2000. Inovasi dan Teknologi Dalam Pengajaran dan Pembelajaran. Selangor: AJM Publishing.

Johnson, D. 1998. CODE 77 Self-Evaluation Rubrics for Basic Teacher Computer Use. An Educator's Guide to Evaluating the Use of Technology in Schools \& Classroom. (Atas talian) http://ed.gov/pubs/EdtechGuide/ appc-6.html (Dilayari pada 13 Februari 2001).

Kulik, C. dan J. A. Kulik. 1991. Effectiveness of Computer-based Instruction. An Updated Analysis. Computers and Human Behavior. 7: 75-94.

Mc Kenzie,J. 1999. How Teachers Learn Technology Best . Bellingham,Washington: FNO Press.

Musa Hj. M. Noor. 1999. Kesediaan Guru-guru KHB di Daerah Pontian dari Segi Kemahiran dan Sikap Terhadap Penggunaan Komputer dalam Aktiviti Pengajaran dan Pembelajaran. Latihan Ilmiah. Universiti Teknologi Malaysia.

Morton, A. 1996. Integrating Computers Across the Secondary School Curriculum. The Western Sydney Experience. (Atas talian) http://www.spirit.net.au/ACE96/papers/mouton.htm (Dilayari pada 21 Jun 2001).

Nadarajan a/ Marimuthu. 2002. Tahap Penggunaan Teknologi Maklumat di Kalangan Guru-guru Ekonomi: Satu Tinjauan. Tesis Sarjana. Universiti Kebangsaan Malaysia.

Nor Hashim Abu Samah, Maznah Yop dan Azlinda Alias. 1996. Komputer Dalam Pendidikan. Kuala Lumpur: Dewan Bahasa dan Pustaka.

Norizan Hj. Ahmad. 1997. Penggunaan Perisian Komputer dalam Proses Pengajaran dan Pembelajaran (Atas talian) http://www.geocities.com/Athens / Delphi/1314/ PERISIAN. HTM (Dilayari pada 14 Jun 2001).

Roszell, D. D. 1995. The Use of Information Technology in Schools. Dlm. R. Krysa, (DEd.). Factors Affecting the Adoption and Use of Computer Technology in Schools, (Atas talian) http://www.usask.ca/education/ coursework/802papers/krysa/ron.htm (Dilayari pada 21 Jun 2001).

Turville, J. 2000. The Role of the Teacher in the Implementation of Technology in Education. (Atas talian). http://www.techlearning.com/db_area/archives/WCE/archives/turville.htm (Dilayari pada 13 Februari 2001). 